九州大学学術情報リポジトリ

Kyushu University Institutional Repository

Evaluation of Water-Saving Methodologies for Rice Farming Using a Distributed Long-Term Rainfall-Runoff Model Incorporated Agricultural Ponds Detected by Multi-Temporal SAR Images in the Ibague Watershed, Colombia

FUKUI, Makoto

Laboratory of Water Environment Engineering, Course of Bioproduction Environmental Sciences, Department of Agro-Environmental Sciences, Graduate School of Bioresource and Bioenvironmental Sciences, Kyushu University

\title{
HIRAMATSU, Kazuaki
}

Faculty of Agriculture, Kyushu University

FUKUDA, Shinji

Division of Agricultural and Environmental Engineering, Institute of Agriculture, Tokyo University of Agriculture and Technology

PINEDA, Dario

FEDEARROZ (National Federation of Rice Growers),

他

https://doi.org/10.5109/4103896

出版情報: 九州大学大学院農学研究院紀要. 65 (2)，pp.313-320，2020-09. Faculty of Agriculture， Kyushu University

バージョン :

権利関係 : 


\title{
Evaluation of Water-Saving Methodologies for Rice Farming Using a Distributed Long-Term Rainfall-Runoff Model Incorporated Agricultural Ponds Detected by Multi-Temporal SAR Images in the Ibague Watershed, Colombia
}

\author{
Makoto FUKUI ${ }^{1}$, Kazuaki HIRAMATSU*, Shinji FUKUDA ${ }^{2}$, Dario PINEDA ${ }^{3}$, \\ Masayoshi HARADA and Toshinori TABATA
}

\author{
Laboratory of Water Environment Engineering, Division of Bioproduction \\ Environmental Sciences, Department of Ago-Environmental Sciences, Faculty of \\ Agriculture Kyushu University, Fukuoka 819-0395, Japan \\ (Received May 15, 2020 and accepted May 27, 2020)
}

\begin{abstract}
A distributed long-term rainfall-runoff model was developed to quantify the watershed scale impacts of water-saving measures in the Ibague watershed, Colombia. The water-saving effects were evaluated by scenario analyses that incorporated the introduction of a water-saving irrigation method (early stopping) to improve irrigation efficiency with respect to redundant paddy irrigation water. In addition to water stopping, the impacts of a new water-saving rice genotype are analyzed. To calculate rainfall-runoff, the Sugawara tank model was utilized. The tank model quantified runoff discharges from forest, upland, paddy field, and urban areas by incorporating each land type into every mesh for a distributed rainfall-runoff model. This quantified the rainfall-runoff characteristics for each land use. Agricultural ponds and irrigation canals were allocated to each corresponding mesh to model irrigation management practices in the watershed. Agricultural ponds, which have a significant effect on the water balance at the watershed scale, were detected by performing cluster analysis on the seasonal transition of the backscatter coefficient obtained from multi-temporal Sentinel-1 SAR images.

Quantitative analyses of the impacts of water-conservation under various scenarios indicated that the early-stopping irrigation method reduced water consumption by $9.4 \%$, compared to the conventional methods. The scenarios, which assumed the introduction of a new water-saving rice genotype, assumed regular irrigation intervals of one or two days and indicated $24.1 \%$ and $48.2 \%$ reductions, for water consumption, respectively, compared to conventional irrigation methods. Scenarios that implemented a new water-saving rice genotype, as well as the early-stopping irrigation method showed reductions of $30.7 \%$ and $53.2 \%$ in water consumption compared to the conventional irrigation method, for the one and two day irrigation periods respectively.
\end{abstract}

Key words: cluster analysis, gap statistic, $k$-means method, satellite remote sensing, watershed-scale water balance

\section{INTRODUCTION}

The Ibague watershed is situated in mid-western Colombia approximately $130 \mathrm{~km}$ west of the capital, Bogota. Maps for elevation, rain-gauge stations, headworks, and land use are shown in Figs. 1 and 2. The Ibague watershed has an area of $1439 \mathrm{~km}^{2}$ and its highest and lowest altitudes are $4955 \mathrm{~m}$ and $243 \mathrm{~m}$, respectively. The monthly maximum and minimum temperatures in the central watershed are $27^{\circ} \mathrm{C}-29^{\circ} \mathrm{C}$ and $18^{\circ} \mathrm{C}-19^{\circ} \mathrm{C}$, respectively. These values are stable throughout the year. The annual rainfall fluctuates significantly throughout the watershed, with an average of approximately $1700 \mathrm{~mm}$. The area has a dry season and a wet season. The dry season is from January to April and from July to

${ }^{1}$ Laboratory of Water Environment Engineering, Course of Bioproduction Environmental Sciences, Department of AgroEnvironmental Sciences, Graduate School of Bioresource and Bioenvironmental Sciences, Kyushu University

Division of Agricultural and Environmental Engineering, Institute of Agriculture, Tokyo University of Agriculture and Technology

FEDEARROZ (National Federation of Rice Growers), Bogota, Colombia

* Corresponding author (E-mail: hiramatsu@bpes.kyushu-u. ac.jp)
August. The wet season is from May to July and from September to November. An alluvial fan spreads out at the center of the watershed with a length of about $25 \mathrm{~km}$ and a ground surface gradient of $2^{\circ}-3^{\circ}$. Rainfall runoff flows into the Magdalena River, which flows along the eastern edge of the watershed. The western part of the watershed is a mountainous area and has no rain-gauge stations. The primary land use in the central and eastern parts of the watershed is agriculture, predominantly rice and coffee, which are cultivated in the plain situated between the central and eastern parts of the watershed.

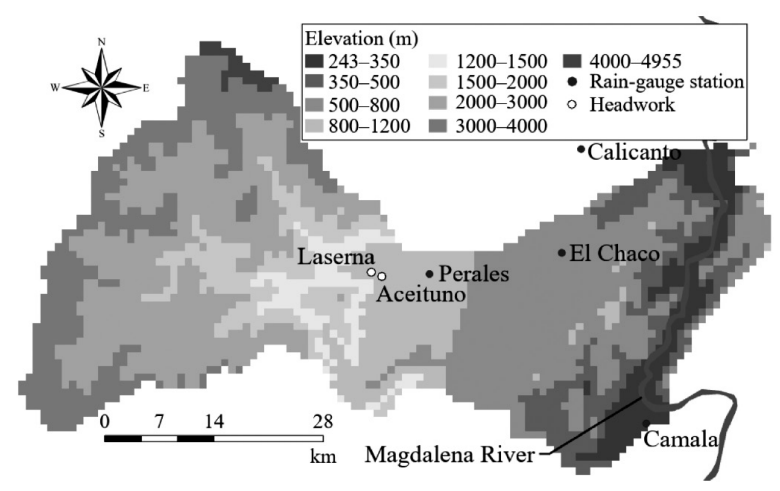

Fig. 1. Digital elevation model, rain-gauge stations and headworks of the Ibague watershed. 


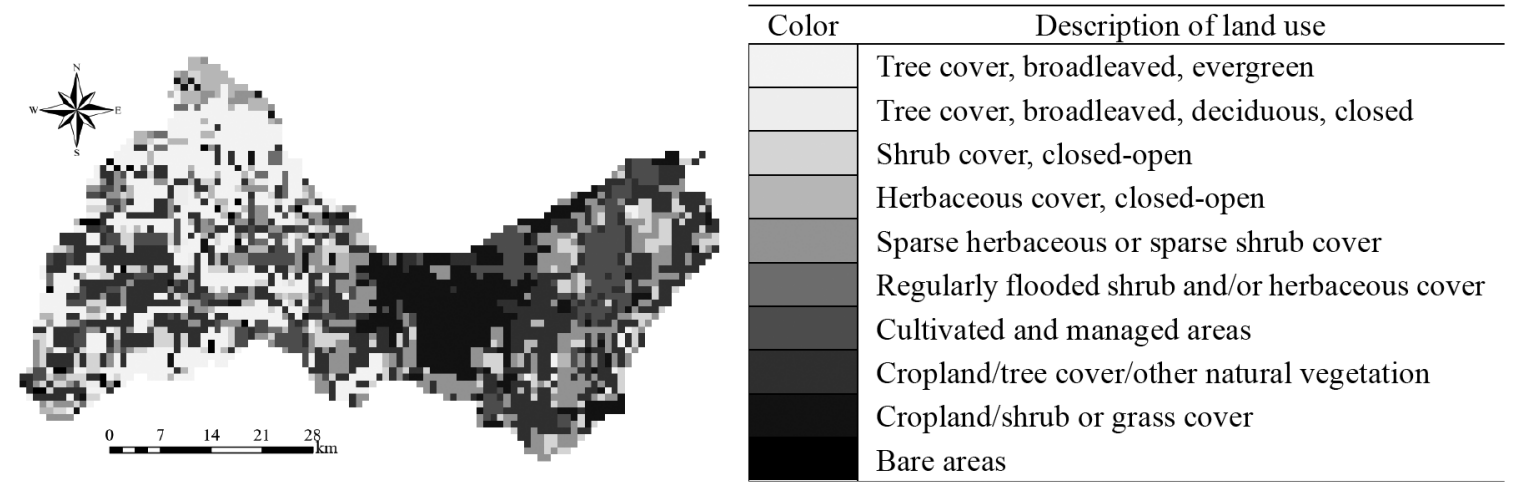

Fig. 2. Land use map of the Ibague watershed.

Each of the paddy-plots in the Ibague watershed generally covers a large area ( 2 ha -20 ha) and has a relatively steep ground surface gradient $\left(2^{\circ}-3^{\circ}\right)$. Therefore, many contour ridges are constructed within a plot, and irrigation water is stored throughout the plot between ridges to maintain water depth, as shown in Fig. 3. Although farmers are aware of the necessity of water conservation, the amount of water use in a plot is greater than the crop requirements because each plot is very wide and the loss of water resulting from management in each paddy-plot is significant. Thus, redundant water usually arises in paddy irrigation.

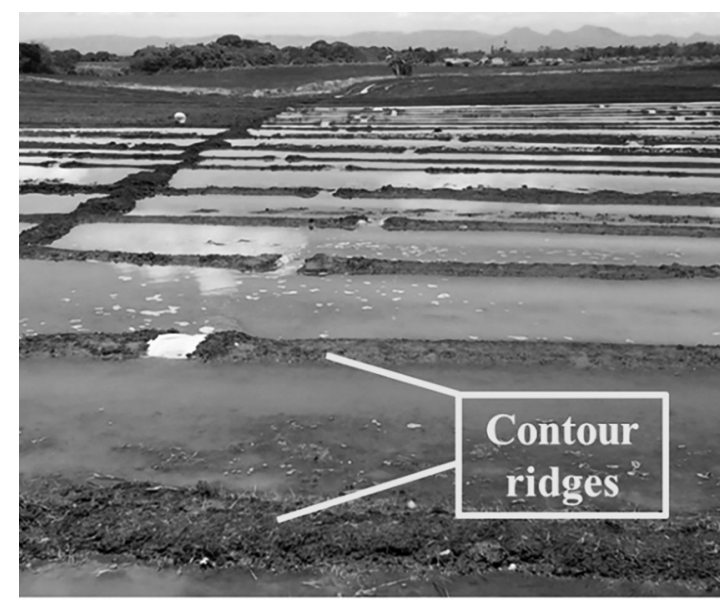

Fig. 3. Paddy field with contour ridges in the Ibague watershed.

In this study, a distributed long-term rainfall-runoff model was constructed in the Ibague watershed to simulate the water balance at the watershed scale. The effects of water conservation in the form of the new paddy irrigation schemes, including early stopping, and a new water-saving rice genotype were evaluated. Scenario analyses that quantified improved irrigation efficiency of early stopping with respect to redundant paddy irrigation was utilized.

A wide variety of distributed rainfall-runoff models such as the TOPMODEL (Beven et al., 1984; Takeuchi et al., 1999; Kazama et al., 2003), Hydro-BEAM (Hydrological river Basin Environment Assessment Model; Kojiri et al., 1998; Park et al., 2003), and
GeoHyMos (Geomorphologically-based Hydrological Modeling System; Ichikawa et al., 2001; Sayama and Takara, 2003; Sayama et al., 2005) have been proposed. In the Ibague watershed, as is the case with those in developing countries, the scarcity and low reliability of necessary hydrological, climatic, and watershed data are significant problems when constructing watershed rainfall-runoff models and conducting water balance simulations using these models. To overcome these problems, a distributed long-term rainfall-runoff model incorporating Sugawara's tank models of several land uses, which was proposed by Takada et al. (2018; 2020a; 2020b), was introduced in this study. In addition, when constructing the rainfall-runoff model, a satellite, remote-sensing technique was utilized to detect agricultural ponds that play an important role in the water balance of the watershed. This was performed to mitigate the effects of the lack of data on actual agricultural ponds in the watershed.

In the Ibague watershed, the Science and Technology Research Partnership for Sustainable Development (SATREPS) Project entitled "Development and Adoption of Latin American Low Input Rice Production System through Genetic Improvement and Advanced Field-management Technologies" was carried out with the support of the Japan Science and Technology Agency (JST) and the Japan International Cooperation Agency (JICA) from FY2013-2017. This study was conducted as part of the project.

\section{MATERIALS AND METHODS}

\section{Detection of agricultural ponds}

To gain a quantitative understanding of the watershed-scale water balance, it is essential to have paddy irrigation accurately incorporated into the rainfall-runoff model because paddy irrigation has a significant effect on the water balance, especially in the Ibague watershed, where paddy field farming is a primary land use in the plain situated between the central and eastern parts of the watershed. However, necessary information was not available in the watershed. This information included the location and area of agricultural ponds, which have an important role as irrigation water 
resources. Therefore, agricultural ponds were detected using a satellite remote sensing technique.

Optical images or synthetic aperture radar (SAR) images are often used for detecting surface water using satellite remote sensing techniques. In this study, SAR images using microwaves, which are less affected by clouds, were used for detecting agricultural ponds because the Ibague watershed has a tropical climate with a high rate of cloudy days. For the detection of surface water or flooded areas from SAR images, the backscatter coefficient, which changes according to land cover and has low value in water areas, has often been utilized for satellite remote sensing. Brivio et al. (2002) and Townsend and Walsh (1998) used a threshold method that classified water bodies and non-water bodies on a certain values of the backscatter coefficient, and Ito et al.(2007) suggests that the determination of the threshold is often ambiguous. In this study, agricultural ponds were detected by a satellite remote sensing technique utilizing the assumption that rivers and ponds are always contain surface water throughout the year and paddy fields are covered by land or water depending on the season. A cluster analysis using the seasonal transition of backscatter coefficient throughout the year was conducted using SAR images.

\section{SAR images}

SAR images were obtained from the Sentinel-1 Interferometric Wide Swath (IW) mode Level-1 Ground

Table 1. Specification of SAR images

\begin{tabular}{cc}
\hline Satellite & Sentinel-1 \\
Wavelength & $\mathrm{C}$ band \\
Polarization & $\mathrm{VV}$ \\
Image mode & IW-SLC \\
Orbit & Ascending \\
Resolution & $20 \mathrm{~m} \times 22 \mathrm{~m}$ \\
\hline
\end{tabular}

Table 2. Date of SAR images

\begin{tabular}{cc}
\hline Image No. & Shooting Date \\
\hline 1 & 14 January 2016 \\
2 & 7 February 2016 \\
3 & 2 March 2016 \\
4 & 19 April 2016 \\
5 & 13 May 2016 \\
6 & 6 June 2016 \\
7 & 30 June 2016 July 2016 \\
8 & 17 August 2016 \\
9 & 28 September 2016 \\
10 & 10 October 2016 \\
11 & 3 November 2016 \\
12 & 27 November 2016 \\
13 & 21 December 2016 \\
14 & \\
\hline & \\
\hline &
\end{tabular}

Range Detected (GRD) product, which contains amplitude information in the ascending orbit direction. The specifications of the SAR images used in this study are shown in Table 1, and the date of 14 SAR images from January to December throughout the year 2016 are summarized in Table 2. Pre-processing steps for the subset of images, including the radiometric calibration, thermal noise removal using a $5 \times 5$ LEE filter, and terrain correction using the Shuttle Rader Topography Mission (SRTM) $3 \mathrm{~s}$ data were performed with an open source tool of Sentinel Application Platform (SNAP) software (SNAP Development Team, 2017). In the terrain correction, the spatial resolution was determined to be $20 \mathrm{~m}$ by considering the size of agricultural ponds and calculation time for the analysis. In the final pre-processing step, pixel digital numbers were converted into sigma noughts in decibels $(\mathrm{dB})$.

\section{Cluster analysis}

The number of pixels on a SAR image for cluster analysis was $2088 \times 2552$ pixels, which yields a total of $5,328,576$ pixels; consequently, the number of elements for cluster analysis was unpractical. Therefore, it was necessary to select a method with a reduced calculation burden. In addition, there is no data on the location of agricultural ponds in the Ibague watershed, which would be used as teacher data (learning data). Therefore, the $k$-means method (MacQueen, 1967), which does not require teacher data and has a short calculation time, was adopted in the cluster analysis. Setting the cluster number is required for the $k$-means method; therefore, the Gap statistic (Pham et al., 2005) which is an evaluation method of the necessary cluster number, was used to determine the cluster number. The Gap Statistic is represented by

$$
\begin{aligned}
& I_{m}=\sum_{t=1}^{N_{m}}\left[d\left(x_{m t}, w_{m}\right)\right]^{2}, \\
& S_{n}=\sum_{m=1}^{n} I_{m}, \\
& f(n)=\left\{\begin{array}{cc}
1 & \left(n=1 \text { or } S_{n-1}=0, \forall n>1\right) \\
\frac{S_{n}}{\alpha_{n} S_{n-1}} & \left(S_{n-1}, \neq 0, \forall n>1\right)
\end{array},\right. \\
& \alpha_{n}=\left\{\begin{array}{cc}
1-\frac{3}{4 N_{d}} & \left(n=2, N_{d}>1\right) \\
\alpha_{n-1}+\frac{1-\alpha_{n-1}}{6} & \left(n>2, N_{d}>1\right)
\end{array}\right.
\end{aligned}
$$

where $m$ is the cluster number, $I_{m}$ is the cluster distortion, $N_{m}$ is the number of objects belonging to cluster $m$, $x_{m, t}$ is the $t$-th object belonging to cluster $m, w_{m}$ is the center of cluster $m, d\left(x_{m, t}, w_{m}\right)$ is the Euclidean distance between objects $x_{m, t}$ and the center $w_{m}$ of cluster $m, n$ is the specified number of clusters, $f(n)$ is the evaluation function, $\alpha_{n}$ is the weight factor, and $N_{d}$ is the number of dataset attributes (i.e., the number of dimensions). When the evaluation function $f(n)$ is less than 1 , the number of clusters is determined to be more appropriate than $n-1$, and when $f(n)$ is greater than 1 , it is determined that $n-1$ is more appropriate than $n$. Because the 
evaluation function was compared with the number of previous clusters, the evaluation function was calculated by the infinite product to compare the whole.

\section{Long-term Rainfall-runoff Model}

In this study, a distributed long-term rainfall-runoff model was constructed based on the model proposed by Takada et al. (2018; 2020a; 2020b). A schematic diagram of the model structure is shown in Fig. 4. To represent conventional paddy irrigation for rice cultivation in the Ibague watershed, irrigation canals and agricultural ponds were incorporated into the rainfall-runoff model. The irrigation canal network was set using canal network data and visible satellite images, and canals were allocated in each corresponding mesh. The agricultural ponds detected by satellite remote sensing using SAR images were allocated to each corresponding mesh. It was assumed that each agricultural pond had a columnlike shape from bottom to surface and had a full water depth of $5 \mathrm{~m}$.

Sugawara's tank model for several land uses were incorporated into the model in common with Takada et al. (2018; 2020a; 2020b). In the Ibague watershed, there were problems related to the scarcity and/or the low-

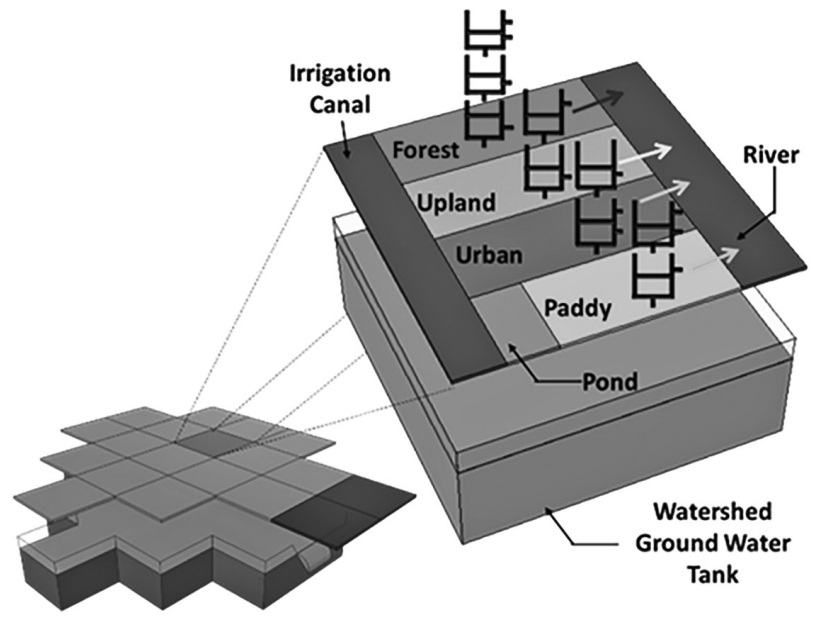

Fig. 4. A distributed long-term rainfall-runoff model.

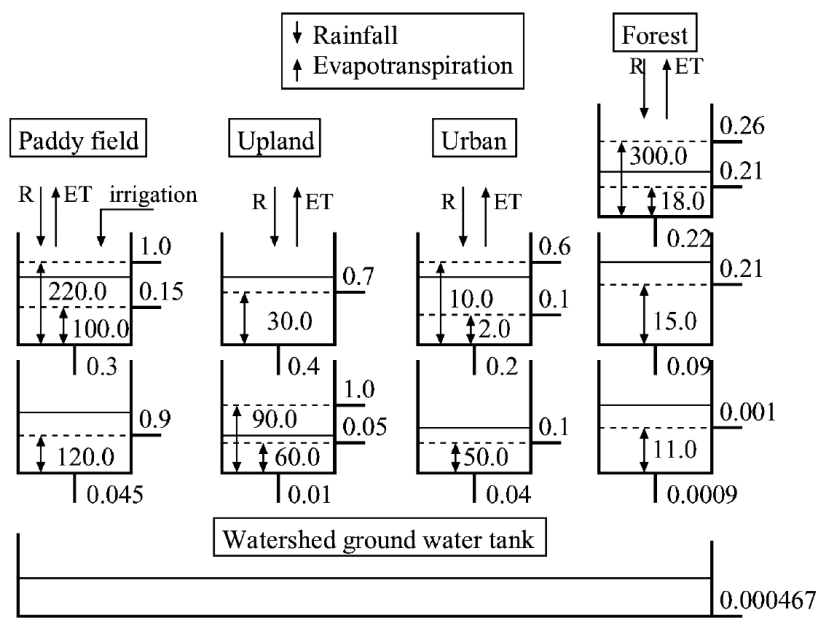

Fig. 5. Structure and parameters of the tank models for the four land uses. reliability of necessary hydro-meteorological and watershed data when constructing rainfall-runoff models. The Sugawara tank model has been previously used for both research and engineering purposes; as a result, the model parameters can be easily estimated with reference to previous studies. In this study, the parameters of the tank models were set by referring to Nakagiri et al. (1998), as shown in Fig. 5. In addition, the actual water management in a paddy-plot was obtained from the interviews with farmers. Also, paddy-plot experiments were conducted to estimate the water demand at a paddy-plot in the Ibague watershed shown in Fig. 6 . Data from both interviews and experiments were used to set the percolation coefficient, irrigation interval, and irrigation water intake for the first tank of the paddy tank model. The paddy-plot experiment in Fig. 6 was conducted in a no-rainfall period. In the rainfall-runoff model, irrigation water for the paddy tank model was taken from the irrigation canal or the agricultural pond in each mesh, and the agricultural pond water was supplied from the river and the irrigation canal in the corresponding mesh. The interviews revealed that the rice cultivation was single cropping with a 120-day cultivation period, and the cultivation season varies in each paddy-plot in the watershed. Therefore, the initiation date of the 120-day cultivation period was set at each mesh by using a uniform random number.

The water flows in the river and the irrigation canal between meshes were simulated based on the kinematic wave method considering the Manning's momentum equation (5) and the continuity equations (6) and (7) that were numerically calculated using the RungeKutta-Gill method.

$$
\begin{aligned}
& Q_{i, j}=\frac{1}{N} B_{i, j} h_{i} R_{i}^{2 / 3} I_{i, j}^{1 / 2}, \\
& \frac{d h_{(k)}^{\text {canal }}}{d t}=\frac{1}{A_{(k)}^{\text {canal }}}\left\{Q_{\text {in }(k)}^{\text {canal }}-Q_{\text {out }(k)}^{\text {canal }}-Q_{\text {irrig }(k)}^{\text {canal }}\right\}+P_{r}-E T,
\end{aligned}
$$

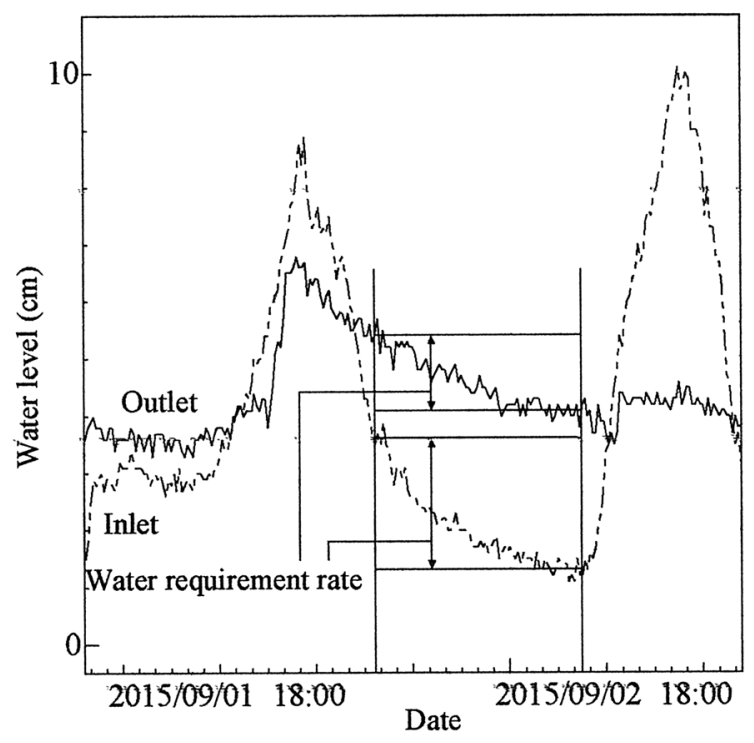

Fig. 6. Variations in water levels measured in a paddy-plot experiment after irrigation water was used. 


$$
\begin{aligned}
& \frac{d h_{(k)}^{\text {river }}}{d t}=\frac{1}{A_{(k)}^{\text {river }}}\left\{Q_{\text {in }(k)}^{\text {river }}-Q_{\text {out }(k)}^{\text {river }}+Q_{\operatorname{tank}(k)}^{\text {river }}+Q_{\text {gwtank }(k)}^{\text {river }}\right. \\
& \left.-Q_{\text {irrig }(k)}^{\text {river }}\right\}+P_{r}-E T,
\end{aligned}
$$

where $i, j$, and $k$ are the mesh numbers, $Q_{i, j}$ is the flow discharge from the mesh $i$ to $j\left(\mathrm{~m}^{3} \mathrm{~s}^{-1}\right), N$ is the Manning's roughness coefficient, which was set to $0.15 \mathrm{~m}^{-1 / 3} \mathrm{~s}$ and $0.023 \mathrm{~m}^{-1 / 3} \mathrm{~s}$ in rivers and irrigation canals based on the standard value of the coefficient in natural water channels and concrete water channels as shown by Chow (1973), $B_{i, j}$ is the mean river width between the mesh $i$ and $j(\mathrm{~m}), h_{i}$ and $h_{k}$ are the water depths in the mesh $i$ and $k(\mathrm{~m}), I_{i, j}$ is the water surface gradient between the mesh $i$ and $j, t$ is the time step $(=300 \mathrm{~s})$, $Q_{\text {in }(k)}$ is the inflow discharge into the mesh $k\left(\mathrm{~m}^{3} \mathrm{~s}^{-1}\right)$, $Q_{\text {out }(k)}$ is the outflow discharge from the mesh $k\left(\mathrm{~m}^{3} \mathrm{~s}^{-1}\right)$, $Q_{\operatorname{tank}(k)}$ is the inflow discharge from the tank models of several land utilizations to the river in the mesh $k\left(\mathrm{~m}^{3}\right.$ $\left.\mathrm{s}^{-1}\right), Q_{\text {gwtank }(k)}$ is the inflow discharge from the watershed groundwater tank model to the river in the mesh $k\left(\mathrm{~m}^{3}\right.$ $\left.\mathrm{s}^{-1}\right), Q_{\text {irrig }(k)}$ is the amount of intake water to ponds in the mesh $k\left(\mathrm{~m}^{3} \mathrm{~s}^{-1}\right), P_{r}$ is the amount of rainfall $\left(\mathrm{m} \mathrm{s}^{-1}\right)$, ET is the amount of evapotranspiration $\left(\mathrm{m} \mathrm{s}^{-1}\right)$ calculated using the Thornthwaite method (Thornthwaite, 1948), and $\mathrm{A}_{(k)}$ is the surface area of the river and irrigation canal in the mesh $k\left(\mathrm{~m}^{2}\right)$. Among the three rain-gauge stations shown in Fig.1, the rainfall data at the station that was determined using the Thiessen polygon method were allocated to the $P_{r}$ at each mesh. The length of the river and irrigation canal in each mesh was assumed to be $4500 \mathrm{~m}$. The canal width was set to be $3 \mathrm{~m}$ based on field observations $\left(\mathrm{A}_{(k)}=3 \mathrm{~m} \times 4500 \mathrm{~m}=13500 \mathrm{~m}^{2}\right)$ and the river width $B_{k}$ at the mesh $k$ was calculated using the following equation (Sayama and Takara, 2003),

$$
B_{k}=B_{0}\left(\frac{A_{k}}{A_{\max }}\right)^{\iota}
$$

where $A$ is the catchment area $\left(\mathrm{m}^{2}\right)$ at the mesh $k, A_{\max }$ is the catchment area at the downstream end $(=4500 \mathrm{~m} \times$ $\left.4500 \mathrm{~m} \times 91=1.84275 \times 10^{9} \mathrm{~m}^{2}\right)$, and $l$ is a constant $(=0.3) . \quad B_{0}$ is the width $(\mathrm{m})$ of the river at the lower reach of the river that flows into the Magdalena River, estimated to be $100.0 \mathrm{~m}$ from a satellite image. The river area $A_{(k)}$ at the mesh $k$ was calculated using $B_{k} \times 4500 \mathrm{~m}$.

\section{Scenario Analyses}

The scenario analyses were conducted for the year 2016. The rainfall data were available at all three raingauge stations shown in Fig. 1 during this year. To quantify the effect of water-saving paddy irrigation, the six scenarios $\mathrm{SC}_{\text {Base }}, \mathrm{SC}_{\mathrm{ES}}, \mathrm{SC}_{01}, \mathrm{SC}_{02}, \mathrm{SC}_{\mathrm{ES} 01}$, and $\mathrm{SC}_{\mathrm{ES} 02}$ were analyzed using the developed model. The scenario $\mathrm{SC}_{\text {Base }}$ was based on rice farming with current irrigation management and irrigation intervals of five- or six-days. According to the paddy-plot experiment data in Fig. 6, the water requirement rate of the paddy field was calculated as $15.9 \mathrm{~mm} / \mathrm{d}$, based on the mean value of the decrease in water depth near the inlet and outlet during the period when irrigation water was not taken and there was no rainfall. In addition, the interviews with farmers revealed that irrigation water was taken only when the paddy surface dried, resulting in an irrigation interval of approximately 5 days -7 days. Therefore, the water depth of irrigation intake into the first tank of the paddy tank model was set to be $44.4 \mathrm{~mm}$ in order to set the intake interval of irrigation water as 5 days when there was no rainfall, and the irrigation water was taken when the water depth of the first tank reached zero.

In the Ibague watershed, the early stopping irrigation method, in which the redundant water in the current irrigation management was cut away by stopping an irrigation intake early, has been widely recommended to mitigate water shortages. The $\mathrm{SC}_{\mathrm{ES}}$ scenario was set by introducing the early stopping irrigation method in the entire basin. The amount of redundant irrigation water in the current irrigation management was estimated to be $4.4 \mathrm{~mm}$ from the paddy-plot experiment, which was determined by the time ratio of the irrigation duration time and the duration when the redundant water occurred. Therefore, the irrigation water intake for the early stopping irrigation method was set to be $40.0 \mathrm{~mm}$ by subtracting the amount of redundant water from the amount of the current irrigation water intake. The timing for supplying the irrigation water was the same as that in the $\mathrm{SC}_{\text {Base }}$ scenario.

Scenarios $\mathrm{SC}_{01}$ and $\mathrm{SC}_{02}$ were set to simulate the effect of introducing a new water-saving genotype of rice, in which the irrigation interval would be extended by one and two days, respectively. The irrigation water was taken one and two days after the water depth of the first tank of the paddy field tank model reached zero in scenarios $\mathrm{SC}_{01}$ and $\mathrm{SC}_{02}$, respectively. The amount of irrigation water intake was the same as that in the $\mathrm{SC}_{\text {Base }}$ scenario.

Scenarios $\mathrm{SC}_{\mathrm{ES} 01}$ and $\mathrm{SC}_{\mathrm{ES} 02}$ were set to simulate the effect of introducing a new water-saving genotype of rice as well as the early stopping irrigation method. The amount of irrigation water intake was the same as that in the SCES scenario. The timing for supplying the irrigation water was the same as that in scenarios $\mathrm{SC}_{01}$ and $\mathrm{SC}_{02}$.

The cumulative amount of irrigation water in the $\mathrm{SC}_{\mathrm{ES}}, \mathrm{SC}_{01}, \mathrm{SC}_{02}, \mathrm{SC}_{\mathrm{ES} 01}$, and $\mathrm{SC}_{\mathrm{ES} 02}$ scenarios for the targeted year 2016 were compared with that of the $\mathrm{SC}_{\text {Base }}$ scenario to evaluate the water-saving effect at the watershed scale.

\section{RESULTS AND DISCUSSIONS}

The evaluation function, $f(n)$, and its infinite product obtained from the Gap Statistic using the entire library of SAR images from January to December throughout 2016 are shown in Fig. 7. In Fig. 7b, it was asymptotic from $n=21$, and it is apparent that there was no significant difference after $n=21$. In addition, in Fig. $7 \mathrm{a}, f(n)$ was greater than 1 in $n=24$, so the appropriate number of clusters was determined to be 23 . The seasonal transition of the backscatter coefficient for each cluster center is shown in Fig. 8 when the number of 
clusters is 23. In this figure, clusters 21 and 23 always showed a smaller backscatter coefficient than the other clusters. Since the backscatter coefficient is relatively small in water areas compared to other land covers, it was concluded that the agricultural ponds and rivers were present in clusters 21 and 23. After removing rivers using visible satellite images, the agricultural ponds were detected. An example of the detected ponds is shown in Fig. 9. In this figure, most of the pond area was successfully detected, but the detected area of agricultural ponds was slightly underestimated. The underestimation could be explained by the fact that increasing or decreasing the water surface area and water level due to water inflow or water usage could not be reflected in detecting the pixels as agricultural ponds. The detected agricultural ponds were incorporated to set up the watershed data set of the rainfall-runoff model.

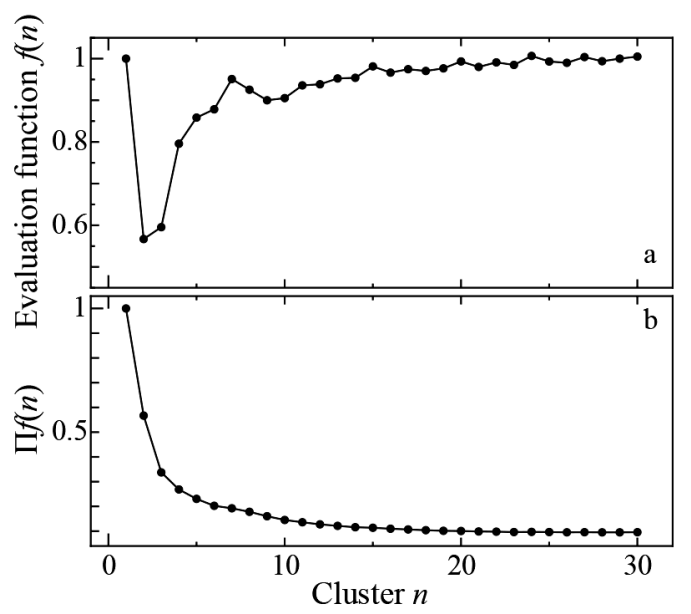

Fig. 7. (a) Evaluation function and (b) infinite product of the evaluation function in the gap statistic.
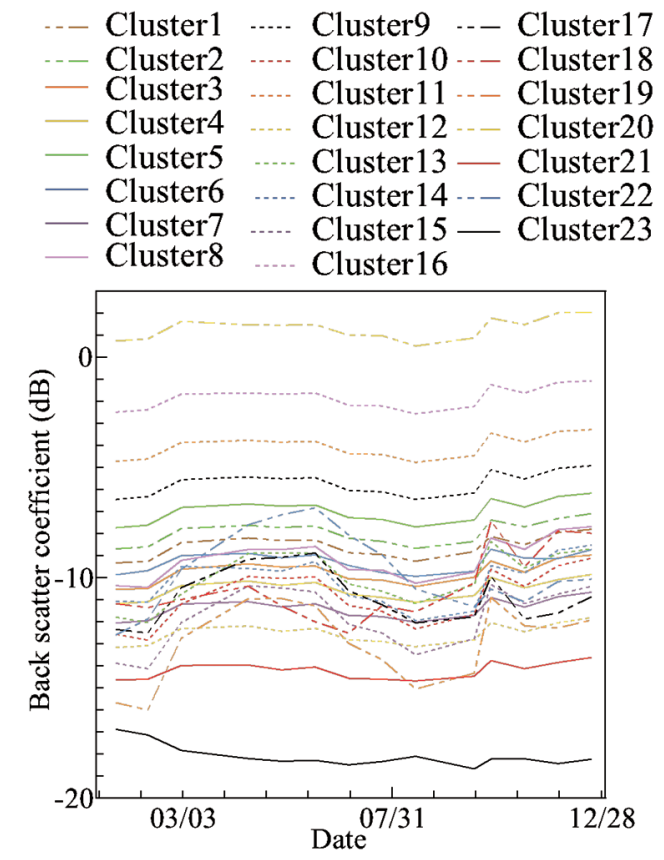

Fig. 8. Seasonal transition of the backscatter coefficient for each cluster center in 2016 ( $n=$ 23).
As mentioned above, in the Ibague watershed, problems exist related to the scarcity and/or low reliability of necessary hydro-meteorological and watershed data when constructing rainfall-runoff models. To overcome these problems, satellite remote sensing technology was introduced to detect the agricultural ponds that are important in the watershed water balance. However, it was impossible to obtain long-term observation data of river discharge that would be indispensable for the validation of the rainfall-runoff model. To cope with this disadvantage, Sugawara's tank models for several land uses were introduced and incorporated into the distributed long-term rainfall-runoff model. Sugawara's tank model has been previously used for both research and engineering purposes. As a result, it is easy to estimate the model parameters with reference to previous studies. Given the scarcity of hydro-meteorological and watershed data in the Ibague watershed, the ability to parameterize Sugawara's tank model was imperative.

The results of the scenario analyses yielded a quantification of the water conservation impacts of the new paddy irrigation scheme, early stopping, with respect to redundant paddy irrigation water. A new water-saving rice genotype is shown in Fig. 10. In the conventional

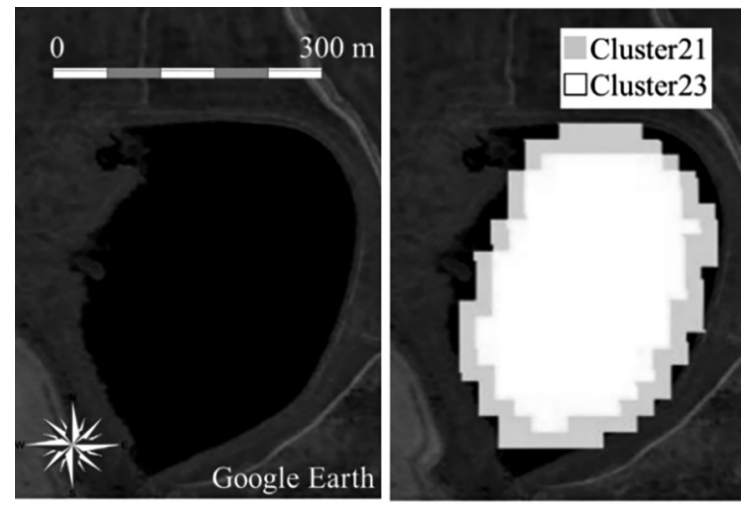

Fig. 9. An example of the detected pond (from Google Earth).

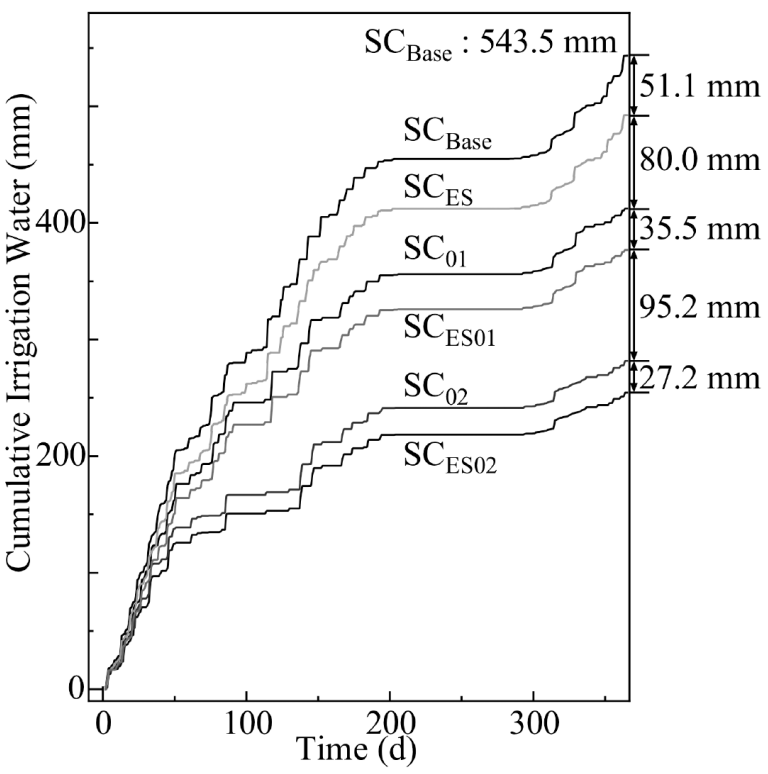

Fig. 10. Annual irrigation water usages for the six scenarios. 
irrigation management of rice farming $\left(\mathrm{SC}_{\text {Base }}\right)$, the annual amount of irrigation water was $543.5 \mathrm{~mm}$. The scenarios $\mathrm{SC}_{\mathrm{ES}}, \mathrm{SC}_{01}, \mathrm{SC}_{02}, \mathrm{SC}_{\mathrm{ES} 01}$ and $\mathrm{SC}_{\mathrm{ES} 02}$ indicated a reduction of irrigation water by $51.1 \mathrm{~mm}, 131.1 \mathrm{~mm}$, $262.0 \mathrm{~mm}, 166.8 \mathrm{~mm}$ and $289.1 \mathrm{~mm}$, respectively from the baseline scenario $\mathrm{SC}_{\text {Base }}$. The spread of the early stopping irrigation method $\left(\mathrm{SC}_{\mathrm{ES}}\right)$ resulted in a $9.4 \%$ reduction in irrigation water, as compared to $\mathrm{SC}_{\text {Base }}$. In scenarios $\mathrm{SC}_{01}, \mathrm{SC}_{02}, \mathrm{SC}_{\mathrm{ES} 01}$, and $\mathrm{SC}_{\mathrm{ES} 02}$, the negative impact of water saving on rice growth was not considered. However, scenarios $\mathrm{SC}_{01}, \mathrm{SC}_{02}, \mathrm{SC}_{\mathrm{ES} 01}$, and $\mathrm{SC}_{\mathrm{ES} 02}$ indicated $24.1 \%, 48.2 \%, 30.7 \%$, and $53.2 \%$ reductions in irrigation water, respectively, from the baseline scenario $\mathrm{SC}_{\text {Base }}$.

\section{CONCLUSIONS}

In this study, a distributed long-term rainfall-runoff model was constructed to simulate the water balance at the watershed scale, and consequently the quantify the impacts of water-saving effects in new paddy irrigation schemes evaluated by scenario analyses introducing a water-conserving, irrigation method, early stopping, to improve irrigation efficiency with respect to redundant paddy irrigation water. In addition, a new water-saving rice genotype in the Ibague watershed, Colombia was analyzed. In constructing the rainfall-runoff model, a satellite remote sensing technique was utilized to detect agricultural ponds that play an important role in the water balance of the watershed. This was done to compensate for the scarcity of data regarding agricultural ponds in the watershed. Long-term observation data of river discharge were absent and are generally indispensable for the validation of the rainfall-runoff model. To compensate for the missing data, Sugawara's tank models for several land uses were introduced and incorporated into the distributed long-term rainfall-runoff model. The Sugawara tank model has been previously used for both research and engineering purposes; as a result, the model parameters can be easily estimated with reference to previous studies. Despite the scarcity of hydro-meteorological and watershed data, especially the river discharge data for verifying the model and the agricultural pond data for constructing the watershed model, the water-saving effects in new paddy irrigation schemes could be quantified at the watershed scale.

\section{AUTHOR CONTRIBUTIONS}

M. Fukui designed the study, performed the numerical simulations, analyzed the simulated data, and authored the paper. K. Hiramatsu designed the study, analyzed the simulated data, and authored the paper. S. Fukuda and D. Pineda performed the field observation, the hearing investigation, the acquisition of hydro-meteorological and watershed data, and assisted in editing the manuscript. M. Harada and T. Tabata assisted in editing the manuscript. All authors approved the final version of the manuscript and agreed to be accountable for all aspects of the work in ensuring that the questions related to the accuracy or integrity of any part of the work were appropriately investigated and resolved.

\section{ACKNOWLEDGEMENTS}

This research was supported in part by the Science and Technology Research Partnership for Sustainable Development (SATREPS) Project "Development and Adoption of Latin American Low Input Rice Production System through Genetic Improvement and Advanced Field-management Technologies" supported by JST and JICA, and the JSPS KAKENHI (Grant number: JP18H03968).

\section{REFERENCES}

Beven, K. J., M. J. Kirkby, N. Schofield and A. F. Tagg 1984 Testing a Physically-based Flood Forecasting Model (TOPMODEL) for Three U. K. Catchments. Journal of Hydrology, 69:119143

Brivio, P. A., R. Colombo, M. Maggi and R. Tomasoni 2002 Integration of remote sensing data and GIS for accurate mapping of flooded areas. International Journal of Remote Sensing, 23(3): 429-441

Chow, V. T. 1973 Open-Channel Hydraulics. International Edition, McGRAW-HILL, New York, pp. 110-113

Ichikawa, Y., M. Murakami, Y. Tachikawa and M. Shiiba 2001 Development of a basin runoff simulation system based on a new digital topographic model. Journal of Japan Society of Civil Engineers, 691:43-52 (in Japanese)

Ito, T., S. Haruyama and S. Oketani 2007 The technique of inundation area extraction and accuracy assessment using JERS-1 SAR (L-band). Journal of the Japan Society of Photogrammetry and Remote Sensing, 46(1): 56-66

Kazama, S., N. B. Nawarathna and M. Sawamoto 2003 Potential water resources estimation in the middle Mekong river region considering irrigation and reservoirs. Proceedings of Hydraulic Engineering, 47:187-192 (in Japanese)

Kojiri, T., A. Tokai and Y. Kinai 1998 Assessment of River Basin Environment though Simulation with Water Quality and Quantity. Disaster Prevention Research Institute Annuals, Kyoto university, 41(B-2):119-134 (in Japanese)

MacQueen, J. 1967 Some methods for classification and analysis of multivariate observations. In: L. Le Cam and J. Neyman, Eds., Proceedings of 5th Berkeley Symposium on Mathematical Statistics and Probability: 281-297

Nakagiri, T., T. Watanabe, H. Horino and T. Maruyama 1998 Development of a hydrological system model in the Kino River Basin -Analysis of irrigation water use by a hydrological system model (I) -. Proceedings of the Japanese Society of Irrigation, Drainage and Rural Engineering, 66(6): 899-909 (in Japanese with English abstract)

Park, J., T. Kojiri and K. Tomosugi 2003 Development of GIS based distributed runoff model for basin wide environmental assessment. Journal of Japan Society of Hydrology and Water Resources, 16(5):541-555 (in Japanese)

Pham, D. T., S. S. Dimov and C. D. Nguyen 2005 Selection of $K$ in $K$-means clustering. Mechanical Engineering Science, 219(C): 103-119

Sayama, T., Y. Tachikawa, K. Takara and Y. Ichikawa 2005 Development of a distributed rainfall-runoff prediction system and assessment of the flood control ability of dams. Journal of Japan Society of Civil Engineers, 803:13-27 (in Japanese)

Sayama T. and K. Takara 2003 A Distributed Sheet Erosion Process Model for Sediment Runoff Prediction. Doboku Gakkai Ronbunshu, 726: 1-9 (in Japanese with English abstract)

SNAP Development Team 2017 Sentinel Application Platform Software. http://step.esa.int/main/toolboxes/snap/ (17 February 2020) 
Takada, A., K. Hiramatsu, N. A. Trieu, M. Harada and T. Tabata 2018 Development of a mesh-based distributed runoff model incorporated with tank models of several land utilizations in a Southeast Asian watershed. Proceedings of the 21st Congress of International Association for Hydro-Environment Engineering and Research - Asia Pacific Division, 1: 539-547

Takada, A., K. Hiramatsu, N. A. Trieu, M. Harada and T. Tabata 2020a Evaluation of impact of climate change and rural development on rainfall-runoff in a Southeast Asian watershed by a distributed model incorporated with tank models for several land use. Proceedings of the 22nd Congress of International Association for Hydro-Environment Engineering and Research-Asia Pacific Division (Accepted)

Takada, A., K. Hiramatsu, N. A. Trieu, M. Harada and T. Tabata 2020b Development of a Distributed Rainfall-runoff Model
Incorporated with Tank Models of Several Land Utilizations and Quantitative Evaluation of Runoff Change Induced by Rural Development and Climate Change. Transactions of the Japanese Society of Irrigation, Drainage and Rural Engineering (Accepted) (in Japanese with English abstract)

Takeuchi, K., T. Ao and H. Ishidaira 1999 Introduction of blockwise use of TOPMODEL and Muskingum-Cunge method for the hydro-environmental simulation of a large ungauged basin. Hydrological Science, 44(4):633-646

Thornthwaite, C. W. 1948 An approach toward a rational classification of climate. Geographical Review, 38(1): 55-94

Townsend, P. A. and S. j. Walsh 1998 Modeling flood plain inundation using integrated GIS with radar and optical remote sensing. Geomorphology, 21: 295-312 